\title{
前浜浸透・滲出流を考慮した波打ち帯の 飽和・不飽和斜面の漂砂輸送解析
}

\author{
宮武 誠 $^{1}$ - 石橋さ $<\zeta^{2} \cdot$ 木村克俊 ${ }^{3}$ - 越智聖志 ${ }^{4} \cdot$ 佐々真志 ${ }^{5} \cdot$ 白水 元 $^{6}$ \\ ${ }^{1}$ 正会員＼cjkstart函館工業高等専門学校准教授 社会基盤工学科（广 042-8501 函館市戸倉町 14 番 1 号） \\ E-mail:miyatake@hakodate-ct.ac.jp \\ ${ }^{2}$ 学生員 函館工業高等専門学校専攻科 社会基盤工学専攻（ $\bar{T} 042-8501$ 函館市戸倉町 14 番 1 号) \\ E-mail:18901@hakodate.kosen-ac.jp \\ ${ }^{3}$ フェロー会員 室蘭工業大学大学院教授くらし環境系領域（广 050-8585 室蘭市水本町 27 番 1 号） \\ E-mail:kimura@mmm.muroran-it.ac.jp \\ ${ }^{4}$ 正会員 日本データーサービス株式会社（广 065-0016 札幌市東区北 16 条東 19 丁目 1 番 14 号) \\ E-mail:m-ochi@ndsinc.co.jp \\ ${ }^{5}$ 正会員 (国研) 海上・港湾・航空技術研究所 港湾空港技術研究所 動土質研究グループ長 \\ ( ₹ 239-0826 横須賀市長瀬 3 丁目 1 番 1 号) \\ E-mail:sassa@ipc.pari.go.jp \\ ${ }^{6}$ 正会員 山口大学大学院助教 社会建設工学分野（７555-0097 山口県宇部市常盤台 2 丁目 16 番 1 号) \\ E-mail:shiro@yamaguchi-u.ac.jp
}

遡上波変形と飽和・不飽和浸透流の結合数值解析モデル及び浸透・渗出流を考慮した浮遊砂輸送モデルを 構築し, 著者らが過去に行った段波作用下における波打ち帯の漂砂可視化実験の再現計算を行い, 数值解析 モデルの再現性を検証するとともに, 波打ち帯の漂砂移動に及ぼす飽和・不飽和斜面の影響について考察 した. 浮遊砂輸送モデルでは, 移流拡散方程式の底面境界条件として課す底質砂の巻き上げ関数に Nielsen の式を採用し，式中に含まれるシールズ数に浸透・滲出流による 2 つの効果を考慮した Turner・Masselink の修正シールズ数を用いることで, 浸透・渗出流の影響を考慮した。 その結果, 斜面を透過とした場合, 計算值は, 実験值と同様に浮遊砂量が遡上時よりも引き波時で大きくなる傾向や飽和斜面に比べ不飽和斜 面の浮遊砂量が遡上時及び引き波時で小さくなる特性を概数良好な結果で評価できることを示した。

Key Words : swash sediment transport, saturation, infiltration and exfiltration, Shields number

\section{1.はじめに}

遡上斜面を透過性と考え，波の遡上に伴う前浜斜面の 浸透・渗出流を考慮した波打ち帯の漂砂解析モデルは過 去に数多く提案されている. 例えば, 浅野・Hoque ${ }^{1)}$ は Carier-Greenspan の理論を用いた斜面上の波浪変形と砂浜 地盤の 2 次元飽和浸透流を仮想薄層を介して結合させた 数值解析から地下水流を推定し, 波打ち帯の漂砂移動に 及ぼす浸透・渗出流の影響に関し，鉛直方向の抗力と境 界層変化の両面から考察している．また， Karambas ${ }^{2}$ は 高次オーダの Boussinesq モデルに鉛直 1 次元浸透・渗出 流を考慮した多孔質媒体のための長波方程式を連成させ た数值解析モデルから水深方向に平均化した水平流速及 び地下水流速を計算し, 修正 Meyer-Peter and Muller の式 により推定された掃流砂量及び水深方向に積分された浮 遊砂輸送モデルによる浮遊砂濃度から波打ち帯の漂砂量
を推定し，実験值との比較から良好な結果が得られてい る. しかし，上記を含めこれまでに提案されたモデルの ほとんどは前浜域の飽和斜面に限定されており，不飽和 斜面を包含したモデルは数少ない. 白水ら ${ }^{334}$ は不飽和 砂層域でのサクション動態が底質の間隙収縮やせん断強 度に影響を及ぼすことを明らかにするとともに，それら が前浜地形の安定に寄与寸ることを指摘している. 以上 のことから不飽和領域を包含した前浜砂層の飽和度は， 波打ち帯の漂砂移動や前浜域の地形変化に重要な役割を 果たしているものと考えられる.

一方，宮武ら ${ }^{5}$ は飽和及び不飽和とした前浜斜面に敷 設した蛍光砂にブラックライトを照射し, 段波作用下に おける波打ち帯の漂砂移動に関する可視化実験を行い, 撮影画像の濃淡值濃度から遡上波流水中の蛍光砂量を計 測し，底質粒径による波打ち帯の漂砂移動に影響を及ぼ す飽和・不飽和浸透流動特性について検討している. 
本研究は，遡上波変形と飽和・不飽和浸透流を水頭を 介して結合させた数值解析モデルならびに，浸透・渗出 流を考慮した浮遊砂輸送モデルを構築し, 上述した段波 作用下における波打ち帯の漂砂可視化実験の再現計算を 行い，数值解析モデルの再現性を検証するとともに，波 打ち帯の漂砂移動に及ぼす飽和・不飽和斜面の影響につ いて考察する.

\section{2. 遡上波変形と前浜浸透流の結合数値解析}

\section{(1) 遡上波変形に関する基本方程式}

前浜浸透流と結合させる砂浜斜面上の遡上波に関す る基本方程式は, 柴山・Duy ${ }^{\text {( }}$ に倣い流速值に波動運 動の位相を基準とした位相平均值を用いた下記に示す Reynolds 方程式及び連続式，水表面の式を用いる.

$$
\begin{aligned}
& \frac{\partial U}{\partial \mathrm{t}}+U \frac{\partial U}{\partial \mathrm{x}}+\bar{W} \frac{\partial U}{\partial z}=-\frac{1}{\rho} \frac{\partial \bar{P}}{\partial \mathrm{x}}+v\left(\frac{\partial^{2} \mathrm{U}}{\partial \mathrm{x}^{2}}+\frac{\partial^{2} \mathrm{U}}{\partial \mathrm{z}^{2}}\right) \\
& +2 \frac{\partial}{\partial x}\left(v_{t} \frac{\partial \bar{U}}{\partial x}\right)+\frac{\partial}{\partial z}\left\{v_{t}\left(\frac{\partial \bar{U}}{\partial z}+\frac{\partial \bar{W}}{\partial x}\right)\right\} \\
& \frac{\partial \bar{W}}{\partial t}+\bar{U} \frac{\partial \bar{W}}{\partial x}+\bar{W} \frac{\partial \bar{W}}{\partial z}=-g-\frac{1}{\rho} \frac{\partial \bar{P}}{\partial z}+v\left(\frac{\partial^{2} \bar{W}}{\partial x^{2}}+\frac{\partial^{2} \bar{W}}{\partial z^{2}}\right) \\
& +2 \frac{\partial}{\partial z}\left(v_{t} \frac{\partial \bar{W}}{\partial z}\right)+\frac{\partial}{\partial x}\left\{v_{t}\left(\frac{\partial U}{\partial z}+\frac{\partial \bar{W}}{\partial x}\right)\right\} \\
& \frac{\partial \bar{U}}{\partial x}+\frac{\partial \bar{W}}{\partial z}=0 \\
& \frac{\partial \zeta}{\partial t}+\frac{\partial}{\partial x} \int_{z h}^{\zeta} \bar{U} \cdot d z=0
\end{aligned}
$$

ここに, $\bar{U}$ 及び $\bar{W}$ は $x$ 及び $z$ 軸方向の位相平均流速, $\bar{P}$ は平均圧力, $\zeta$ は水表面の高さ, $z h$ は底面の高さ, $g$ は 重力加速度, $\rho$ は流体密度, $v$ は動粘性係数を示す. $v_{t}$ は渦動粘性係数を示し, Bakhtyar ${ }^{7}$ の研究を参考にして 2 方程式乱流モデルにより決定した。遡上波の解析に使用 した計算パラメータを表-1 に示す。

\section{(2) 前浜浸透流に関する基本方程式}

遡上波と結合させる砂浜内の浸透流は，遡上波によっ て地下水位が絶えず変化する不圧帯水層全域を対象とす るため, 基本方程式には, Bear ${ }^{\text {g) }}$ の飽和 - 不飽和浸透流 方程式を用いる. 砂層内は等方性均質多孔体と仮定すれ ば，以下のように表される.

\begin{tabular}{|c|c|c|c|c|c|c|}
\hline \multirow{7}{*}{$\begin{array}{c}\text { 遡上波変形 } \\
\text { 計算 }\end{array}$} & \multirow{2}{*}{ Reynolds 方程式 } & \multicolumn{3}{|c|}{ 流体密度 } & $\rho\left(\mathrm{g} / \mathrm{cm}^{3}\right)$ & 1.0 \\
\hline & & \multicolumn{3}{|c|}{ 動粘性係数 } & $v\left(\mathrm{~cm}^{2} / \mathrm{s}\right)$ & 0.010 \\
\hline & \multirow{5}{*}{$\begin{array}{c}2 \text { 方程式 } \\
(\kappa-\varepsilon \text { 方程式 })\end{array}$} & \multirow{5}{*}{\multicolumn{2}{|c|}{ 定数 }} & \multicolumn{2}{|r|}{$C_{\mu}$} & 0.09 \\
\hline & & & & & $\sigma_{\varepsilon}$ & 1.30 \\
\hline & & & & \multicolumn{2}{|r|}{$\sigma_{\kappa}$} & 1.0 \\
\hline & & & & \multicolumn{2}{|r|}{$C_{\varepsilon 1}$} & 1.44 \\
\hline & & & & \multicolumn{2}{|r|}{$C_{\varepsilon 2}$} & 1.92 \\
\hline \multirow{9}{*}{$\begin{array}{c}\text { 前浜浸透流 } \\
\text { 計算 }\end{array}$} & \multirow{3}{*}{$\begin{array}{c}\text { 飽和・不飽和 } \\
\text { 浸透流方程式 }\end{array}$} & \multicolumn{2}{|c|}{ 比貯留係数 } & & 0.011 \\
\hline & & \multirow{2}{*}{\multicolumn{3}{|c|}{\begin{tabular}{|l} 
飽和透水係数 \\
べき定数
\end{tabular}}} & & 0.014 \\
\hline & & & & & $\gamma$ & 3.0 \\
\hline & \multirow{6}{*}{$\begin{array}{c}\text { 水分保持特性 } \\
\text { 曲線 } \\
\text { (Van-Genuchten } \\
\text { の式) }\end{array}$} & & & \multicolumn{2}{|c|}{ 及水過程 排 } & 水過程 \\
\hline & & \multirow{3}{*}{ 定数 } & $a$ & \multicolumn{2}{|c|}{0.0344} & 0.0211 \\
\hline & & & & & .7970 & 0.7893 \\
\hline & & & $n$ & & 9260 & 4.7458 \\
\hline & & \multirow{2}{*}{\multicolumn{2}{|c|}{$\begin{array}{l}\text { 飽和 } \\
\text { 水分量 } \theta_{s} \\
\text { 残留 } \\
\text { 水分量 } \theta_{r}\end{array}$}} & \multicolumn{2}{|c|}{0.4691} & 0.5063 \\
\hline & & & & & 0115 & 0.0173 \\
\hline
\end{tabular}

$$
\begin{gathered}
(u, w)=-K(\psi)\left(\frac{\partial \psi}{\partial x}, \frac{\partial \psi}{\partial z}+1\right) \\
\left\{S_{w} S_{s}+C(\psi)\right\} \frac{\partial \psi}{\partial t}=\frac{\partial}{\partial x}\left\{K(\psi) \frac{\partial \psi}{\partial x}\right\} \\
+\frac{\partial}{\partial z}\left\{K(\psi)\left(\frac{\partial \psi}{\partial z}+1\right)\right\}
\end{gathered}
$$

ここに, $\psi$ は飽和時において圧力水頭 $(>0)$, 不飽和時
表 -1 計算パラメータの諸元 (結合数值解析)

では毛管水頭 $(<0), u, w$ は $x, z$ 軸方向の浸透流速， $K(\psi)$ は透水係数 $\left(=K_{s} S_{w}^{\gamma}\right), S_{w}$ は飽和度 $\left(=\left(\theta \theta_{r}\right) /\left(\theta_{s}-\theta_{r}\right)\right), \theta$ は水分量, $\theta_{s}$ は飽和水分量, $\theta_{r}$ は残留水分量を示す. $\gamma$ はべき定数であり， Imay ${ }^{9}$ による值を採用する． $K_{s}$ は飽 和透水係数, $S_{s}$ は比貯留係数, $C(\psi)$ は比水分容量を示す. 不飽和砂層内の透水係数及び比水分容量の算定に必要 な水分量 $\theta$ と毛管水頭 $\psi$ の関係には, 以下に示寸 VanGenuchten ${ }^{10)}$ の式を用いる.

$$
\theta=\theta_{s}+\left(\theta_{s}-\theta_{r}\right)\left\{\frac{1}{1+(a|\psi|)^{n}}\right\}^{m}
$$

ここに， $a, m, n$ は経験的に定める定数である. 浸透流の 計算に用いる土㙥パラメータは, 後述する漂砂可視化実 験で使用した底質砂に対する実測值を表 -1 のように与 えている.

\section{(3) 計算方法}

(1) 式から (7) 式は, 前浜砂層内の浸透流との結合を考 え，遡上波における水表面の時間的変動をより正確に計 算するため, 自然座標系に変換した後, 差分法により計 算を行う。波の計算に関する水表面及び底面に関する境 界条件及び波打ち帯における遡上計算は, 柴山・Duy の方法を準用する. 沖側の境界から入射させる波は, 後 出の漂砂実験で使用したゲート水位を初期条件として与 えて段波を発生させる. 一方, 浸透流に関する境界条件 は, 水路床部の境界を不透過として取り扱い, 後浜側の 境界には漂砂実験で設定した後浜水位を圧力水頭として 与える.また，遡上波と結合させる砂浜斜面上の浸透流 に関する境界格子点には, 波の計算で得られた遡上波水 深を圧力水頭として与える. 


\section{3. 浸透・滲出流を考慮した浮遊砂輸送解析}

\section{（1）遡上波流水中の浮遊砂輸送に関する基本方程式}

遡上波流水中の浮遊砂移動に関しては，浮遊砂の沈降 速度が時間によらず一定の值をとるものとし，以下に示 す移流拡散方程式を用いる.

$$
\begin{aligned}
\frac{\partial \bar{C}}{\partial t} & +\frac{\partial(\bar{C} \bar{U})}{\partial x}+\frac{\partial(\bar{C} \bar{W})}{\partial z} \\
& =\frac{\partial}{\partial x}\left(\varepsilon_{s x} \frac{\partial \bar{C}}{\partial x}\right)+\frac{\partial}{\partial z}\left(\varepsilon_{s z} \frac{\partial \bar{C}}{\partial z}\right)+w_{f} \frac{\partial \bar{C}}{\partial z}
\end{aligned}
$$

ここに, $\bar{C}$ は位相平均した浮遊砂濃度， $w_{f}$ は底質砂の沈 降速度であり, Rubey ${ }^{11)}$ の実験式を用いる。 $\varepsilon_{s x}, \varepsilon_{\mathrm{sz}}$ は $x$ 及 び $\mathrm{Z}$ 軸方向における浮遊砂の濃度拡散係数を示し，本計 算では前出の渦動粘性係数の関数 $\left(\varepsilon_{s x}=\varepsilon_{s z}=\beta v_{t}\right)$ として取 り扱い, $\beta$ は希薄な遡上波流水中の浮遊砂が流体運動に よる乱流拡散に十分追従すると仮定して，表-2のよう に与える.

\section{(2) 計算方法}

(8) 式の計算は前述の結合数值解析に倣い，自然座標 系に変換後，差分法により計算する. 境界条件として， 水表面に関しては，水表面を通じて浮遊砂フラックスは ゼロであるとする以下の条件を適用する。

$$
\varepsilon_{s z} \frac{\partial \bar{C}}{\partial z}+\bar{C} w_{f}=0
$$

これに対し，底面に関する境界条件はこの境界面を通じ て乱流拡散により上方に運ばれる浮遊砂フラックスと底 面から巻き上げられるフラックスが釣り合うとして，以 下のように与える

$$
\varepsilon_{s z} \frac{\partial \bar{C}}{\partial Z}=-P_{w}
$$

ここに， $P_{w}$ は底質の巻き上げ率を示し，本計算では， 以下に示す Nielsen $^{12)}$ によって提案された巻上げ関数を使 用する。

$$
P_{w}= \begin{cases}C_{p}\left(\frac{\Theta-\Theta_{c}}{\Theta_{c}}\right)^{1.5} \frac{(s-1)^{0.6} g^{0.6} d^{0.8}}{v^{0.2}} & \Theta>\Theta_{c} \\ 0 & \Theta \leq \Theta_{c}\end{cases}
$$

ここに, $s$ は底質砂の比重 $\left(=\rho_{s} / \rho\right), \rho_{s}$ は底質砂の密度, $d$ は底質砂の中央粒径， $\Theta$ はシールズ数であり，次節に 詳述する. $\Theta_{c}$ は限界シールズ数， $C_{p}$ は経験的な定数で あり，それぞれ Nielsen ${ }^{12)}$ 及び中村ら ${ }^{13)}$ の研究を参考に して表-2のように与える.

\section{（3）不透過及び透過斜面に対するシ一ルズ数の評価}

\begin{tabular}{|c|c|c|c|c|}
\hline \multirow{7}{*}{$\begin{array}{c}\text { 浮遊砂輸送 } \\
\text { 計算 }\end{array}$} & 移流拡散方程式 & 定数 & $\beta$ & 1.0 \\
\hline & \multirow{2}{*}{$\begin{array}{c}\text { 巻上げ関数 } \\
\text { (Nielsen の式) }\end{array}$} & 経験的な定数 & $C_{p}$ & 0.04 \\
\hline & & 限界 Shields 数 & $\Theta_{c}$ & 0.05 \\
\hline & \multirow{4}{*}{$\begin{array}{c}\text { シールズ数 } \\
\text { (無次元掃流力) }\end{array}$} & 摩擦係数 & $f$ & 0.03 \\
\hline & & 中央粒径 & $d(\mathrm{~mm})$ & 0.1 \\
\hline & & 比重 & $s$ & 2.67 \\
\hline & & $\begin{array}{l}\text { 経験的な } \\
\text { 無次元定数 }\end{array}$ & $\begin{array}{l}\beta_{s} \\
c\end{array}$ & $\begin{array}{l}0.50 \\
2.0\end{array}$ \\
\hline
\end{tabular}

砂浜斜面を不透過と考えた場合，以下に示寸遡上波掃 流に対するシールズ数 $\Theta_{0}$ を，(11) 式中の $\Theta$ に代入して 計算を行う。
表 -2 計算パラメータの諸元 (浮遊砂輸送解析 )

$$
\Theta_{0}=\frac{\tau_{0}}{W_{0}}=\frac{0.5 \rho_{w} f \bar{U}_{s}\left|\bar{U}_{s}\right|}{\rho_{w} g d(s-1)}
$$

ここに， $\tau_{0}$ は不透過斜面の底面掃流力， $W_{0}$ は底質砂の 水中自重, $\bar{U}_{s}$ は遡上波による底面流速の斜面方向成分 を示し，岸向き方向を正，沖向き方向を負とする，fは 摩擦係数であり，Masselink ${ }^{14)}$ らに倣い，表-2 に示す值 を用いる。

これに対し，Tumer・Masselink ${ }^{15)}$ は透過斜面とした場 合，遡上斜面上で生じる浸透・滲出流による 2 つ作用 として, 底質砂の有効自重を増減させる効果と境界層構 造の変化により底面掃流力を増減させる効果を，それぞ れ (12) 式中の分母及び分子に考慮した透過斜面に対する 修正シールズ $\Theta_{w}$ を以下のように提案している.

$$
\Theta_{w}=\frac{\tau_{w}}{W_{w}}=\frac{\tau_{0}\left(\frac{\Phi}{e^{\Phi}-1}\right)}{\rho g d\left(s-1-\beta_{s} \frac{W_{s}}{K(\psi)}\right)}
$$

ここに， $\tau_{w}$ は透過斜面の底面掃流力， $W_{w}$ は底質砂の有 効自重, $w_{s}$ は浸透を負, 滲出を正とする浸透・滲出流 速の斜面垂直成分, $\Phi$ は $c / f \cdot w_{s} /\left|\bar{U}_{s}\right|$ であり, 経験的に 定める無次元定数である $c$ 及び $\beta_{s}$ は, Butt ${ }^{16)}$ に従い 表 -2 に示寸值を用いる. 砂浜斜面を透過として取り扱 う場合は，この修正シールズ $\Theta_{w}$ を (11) 式中の $\Theta$ に代入 して計算することとする.

\section{4. 波打ち帯における漂砂可視化実験の再現計算}

\section{(1) 模型実験の概要及び計算ケース}

宮武ら ${ }^{5)}$ による段波作用下における波打ち帯の漂砂可 視化実験の再現計算を行い，数值解析モデルの再現性を 検証するとともに，波打ち帯の漂砂移動に及ぼす飽和・ 不飽和斜面の影響について考察する。実験は図 -1 に示 す，底質を硅砂で構成した海底勾配 $1 / 10$ の砂浜模型に 沖側のゲート水位 $h$ により段波を作用させ，初期汀線か ら $25 \mathrm{~cm}$ 岸側の遡上波水位及び地下水位を計測するとと もに, $50 \mathrm{~cm}$ 岸側には前浜斜面に敷設した蛍光砂にブラッ クライトを照射し，水槽側面より撮影した遡上波流水中 
の蛍光砂の画像濃淡濃度から濃度変換曲線により蛍光砂 層上部を通過する単位幅あたりの蛍光砂量を求めてい る. 実験ケースは 2 種の粒径の底質に対し, 後浜水位 $h^{\prime}$ を変化させて砂浜斜面を飽和及び不飽和とした全 4 ケー スで行われているが，本計算ではその中でも実験におい て浮遊砂の卓越する中央粒径 $d_{50}=0.1 \mathrm{~mm}$ の細砂を対象に 飽和及び不飽和斜面とした場合に加え，比較のため斜面 を不透過とした全 3 ケース実施した（表一3）.

\section{(2) 計算条件}

座標軸は, 図 -1 中の $A$ 点を原点とし, 岸沖方向に $x$ 軸，鉛直方向に $z$ 軸を設定する．計算では，蛍光砂層上 部を通過する単位幅あたりの蛍光砂量を再現するにあた り, 蛍光砂層区間を移動床とし, その他の砂浜斜面は固 定床として取り扱う. 沖側の境界から入射させる段波は, 表 -3 中に示寸実験で使用したゲート水位 $h$ を用いて発 生させる. 浸透流計算において後浜側の境界から圧力水 頭として与える後浜水位 $h^{\prime}$ は飽和・不飽和斜面に応じ, 同表中に示寸実験值を用いる. なお, 不透過斜面の場合, 浸透流計算は行わず, 段波計算のみで浮遊砂を計算する.

\section{5. 解析結果の検証と考察}

\section{（1）遡上波水位及び前浜地下水位の検証}

図-2 及び3の (a) と (b) はそれぞれ，初期汀線から $25 \mathrm{~cm}$ 岸側地点で計測された飽和及び不飽和斜面におけ る遡上波水位と地下水位の実験值と計算值を比較したも のを示す．両図 (a) に示す遡上波水位の実験值は, 同じ 段波条件にも関わらず，水位上昇時に若干の違いが認め られる.この要因としては計測装置の応答特性による問 題や砂浜斜面の飽和度に伴う砂層内一の浸透の影響等が 考えられるが，実験值からその要因を究明することは難 しい. より詳細な検証は今後の課題として残るものの, 遡上波水位の計算值は，実験值の傾向を概水再現してい るといえる. 一方, 両図の (b) に示寸地下水位の実験值は, 斜面の飽和度に依らず遡上波水位の上昇にやや遅れて応 答するが，その上昇量は飽和斜面よりも不飽和斜面に対 して大きくなる，上昇後は，地下水位が速やかに初期地 下水位までほぼ低下する飽和斜面に対し, 不飽和斜面で はある程度低下した後, 初期地下水位よりも高い水位を 維持している. 地下水位の計算值は, こういった実験值 の特性を良好な結果で予測している。

\section{（2）透過斜面のシールズ数及び浮遊砂量の検証}

図 -4 及び 5 の (a) は遡上波と浸透流の結合数值解析モ デルで得た初期汀線から 50cm 岸側地点の飽和及び不飽 和斜面における遡上波底面流速及び浸透・滲出流速を示 す. 飽和斜面とした場合, 遡上時に生じる浸透流速とほ

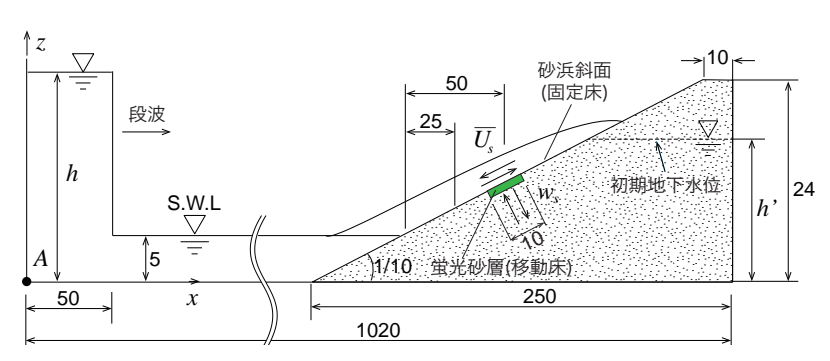

図 -1 模型実験の概要図 (単位：cm)

表 -3 計算ケース

\begin{tabular}{c|c|c|c|c}
\hline ケース & $\begin{array}{c}\text { 沖側ゲート } \\
\text { 水位 } h(\mathrm{~cm})\end{array}$ & $\begin{array}{c}\text { 後浜水位 } \\
h^{\prime}(\mathrm{cm})\end{array}$ & $\begin{array}{c}\text { 遡上斜面 } \\
\text { の状態 }\end{array}$ & $\begin{array}{c}\text { 底質の粒径 } \\
d_{50}(\mathrm{~mm})\end{array}$ \\
\hline Run1 & 40.0 & 15.0 & 飽 和 & 0.1 \\
Run2 & 40.0 & 5.0 & 不飽和 & 0.1 \\
Run3 & 40.0 & - & 不透過 & 0.1 \\
\hline
\end{tabular}
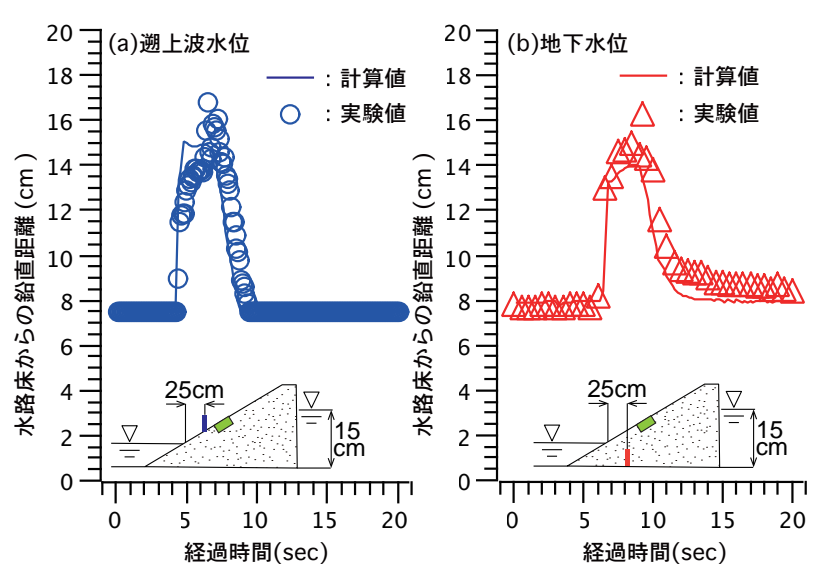

図 -2 遡上波水位及び地下水位の比較 (Run1, 飽和斜面)
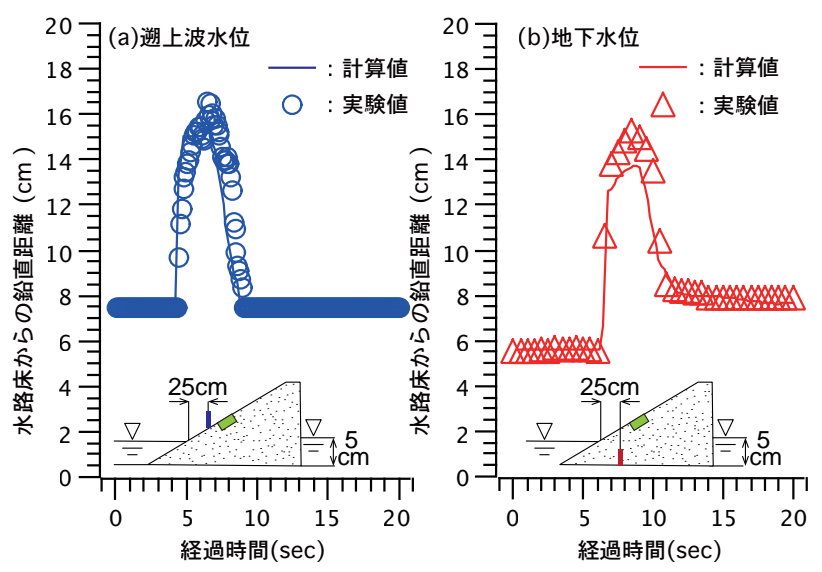

図 -3 遡上波水位及び地下水位の比較 (Run2, 不飽和斜面)

ぼ同程度の渗出流速が引き波時に生じるのに対し，不飽 和斜面の場合では, 飽和斜面よりも大きな浸透流速が長 時間に渡り発生し, 滲出流速は減速寸る。これは遡上時 に前浜砂層内に浸透した遡上水のほとんどが引き波時の 滲出流となって砂層外に流出する飽和斜面に対し, 不飽 和斜面ではより多くの遡上水が前浜砂層に浸透し, 貯留 されたことを示唆しており, 計測地点が異なるものの前 述した飽和及び不飽和斜面における地下水位の上昇量や 

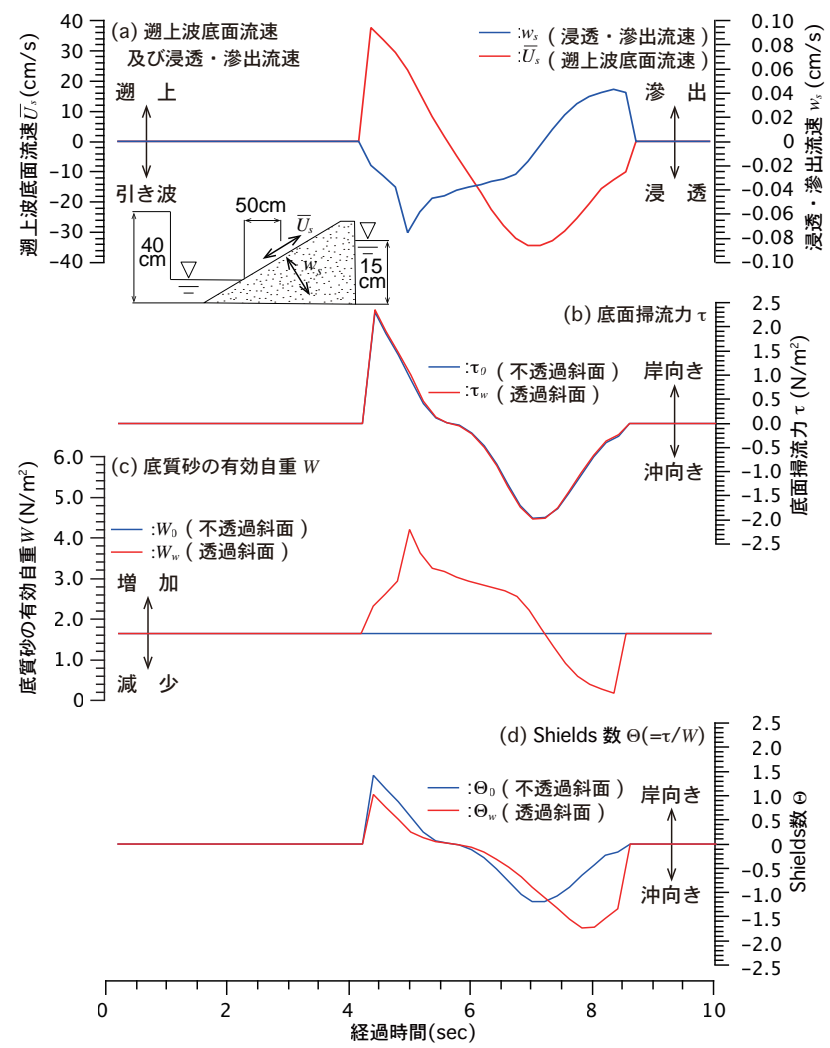

図 -4 飽和斜面 (Run1) に抢ける浸透・滲出流速，底質砂 の有効自重，底面掃流力，シールズ数の経時変化

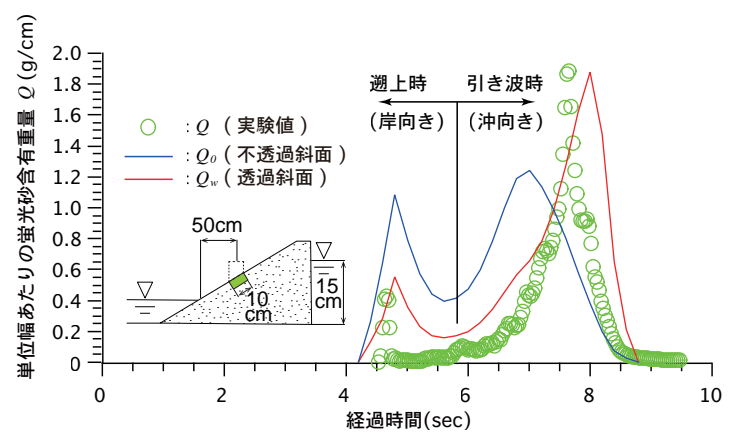

（a）飽和斜面の場合 (Run1)
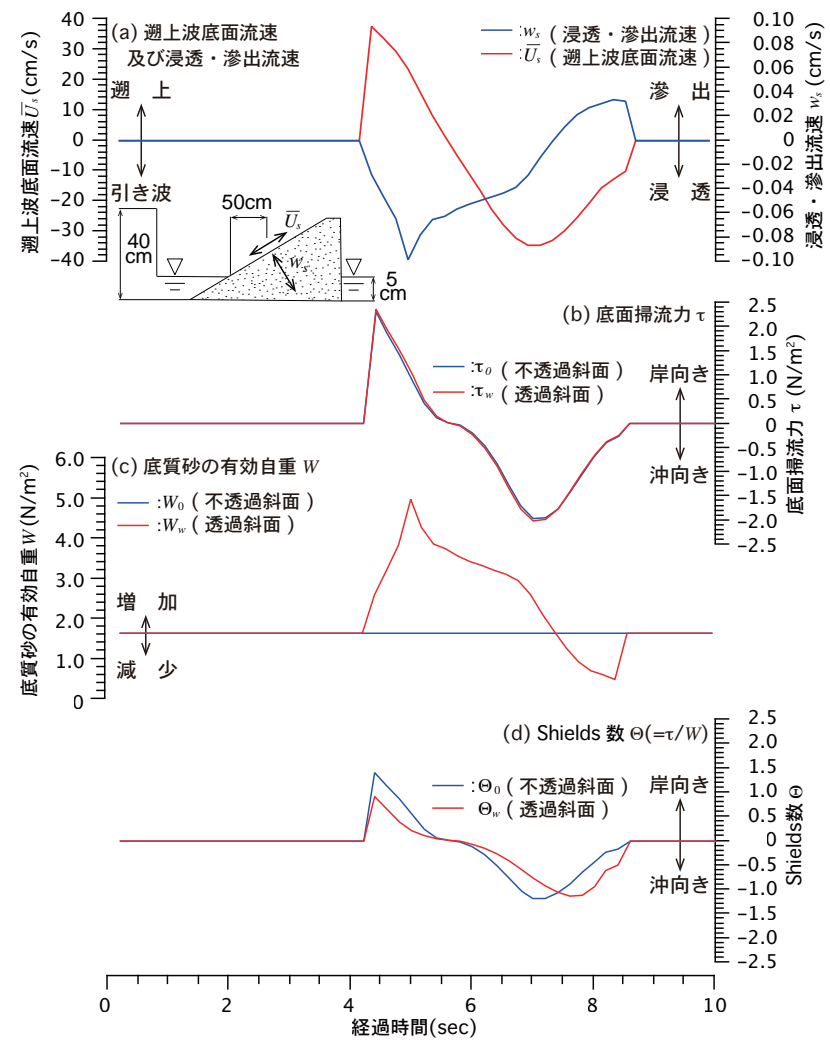

図 -5 不飽和斜面 (Run2) における浸透・渗出流速，底質砂 の有効自重，底面掃流力，シールズ数の経時変化

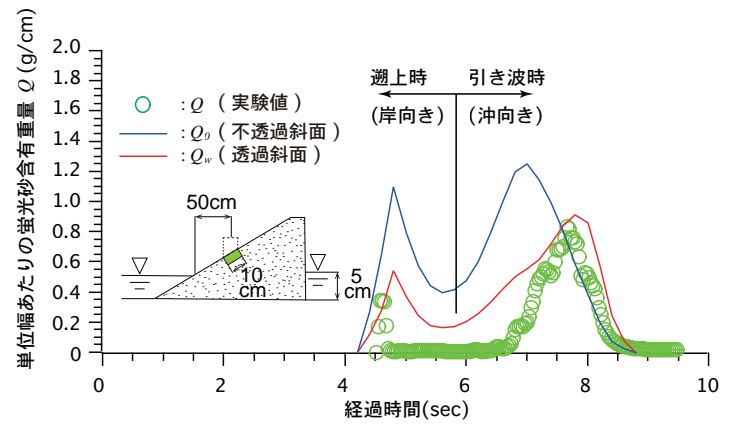

(b) 不飽和斜面の場合 (Run2)

図 -6 透過斜面と不透過斜面における蛍光砂量の計算值と実験值の比較

降下特性の結果とも整合寸る. 両図 (b) は斜面を透過及 び不透過とした場合の底面掃流力を示寸．飽和及び不飽 和斜面でともに不透過斜面とした場合との差が微小であ ることから，浸透・滲出流が遡上波による底面掃流力の 増減に及ぼす影響は，本計算で対象とした細砂において は小さいといえる。一方，両図 (c) に示寸底質砂の有効 自重は，浸透・滲出流の作用により，飽和及び不飽和斜 面でともに不透過斜面に比して遡上時に増加し，引き波 時に減少する.この結果, 両者の比を表寸両図(d)のシー ルズ数は，岸向き及び沖向きの絶対值がほぼ同程度とな る不透過斜面に対し，透過斜面とした場合では浸透・沴 出流による底質砂の有効自重変化が主な要因となって, 飽和及び不飽和斜面でともに岸向きよりも沖向きの絶対 值の方が大きくなる. また, 飽和・不飽和斜面による浸透・ 滲出流速の特性に応じて底質砂の有効自重が増減するた
め，飽和斜面は不透過斜面に比して岸向きに減じ，沖向 きに増加するが，不飽和斜面では飽和斜面の場合よりも 岸向き及び沖向きでともに減少する.

図一(a) 及び(b) は斜面を透過とし，飽和及び不飽和と した場合の蛍光砂層上部を通過する単位幅あたりの蛍光 砂量の計算值と実験值の比較を示し，図中には不透過斜 面に対する計算值も表示する. 実験と同様に蛍光砂層上 部における遡上波流水中の浮遊砂濃度を積分して求めた 計算值はシールズ数の特性に対応して, 不透過斜面の場 合では遡上時及び引き波時でほぼ同程度となり, 飽和及 び不飽和斜面の実験值の傾向とは異なった結果となる. これに対し，透過斜面とした場合では，実験值と同様に 遡上時よりも引き波時の方が大きくなる傾向や飽和斜面 に比べ不飽和斜面の蛍光砂量が遡上時及び引き波時でと もに小さくなる特性を概ね良好な結果で再現できる. 


\section{6. 結 論}

本研究は，遡上波と浸透流の結合数值解析に浸透・滲 出流を考慮した浮遊砂輸送解析を加えた数值モデルによ り，過去に実施した漂砂実験の再現計算を行い，その再 現性及び波打ち帯の漂砂移動に及ぼす飽和・不飽和斜面 の影響を検証した。その結果，計算值は細砂で構成され た飽和及び不飽和斜面における波打ち带の漂砂量の特性 を概ね良好な結果で評価できることを示すとともに，波 打ち帯の漂砂移動は, 飽和度に応じ発生する浸透・滲出 流によって底質砂の有効自重を増減させる効果が深く関 わっていることを明らかにした，今後は，遡上波水位の 再現精度の向上に加え, 連続した進行波への適用及び底 質濃度の乱流モデルへの導入を検討する所存である。

謝辞: 本研究は学術研究助成基金助成金 基盤研究 (c)（課 題番号 16K06521）の補助を受けた. ここに記して謝意 を表す。

\section{参考文献}

1) 浅野敏之, Md. Azharul Hoque: 境界層の変化を考慮した 透水性斜面上の漂砂の解析, 海岸工学論文集, 第 50 巻, pp.501-505, 2003.

2) Karambas, T. V. : Prediction of sediment transport in the swashzone by using a nonlinear wave model, Continental Shelf Research 26 pp.599-609, 2006.

3) 白水 元, 佐々真志, 宮武 誠, 本間大輔, 成田郁史 : 高波作用下の前浜平衡勾配に及ぼす間隙サクション動 態効果の影響, 土木学会論文集 B3 (海洋開発), Vol. 72, No. 2, I_712-I_717, 2016.

4) 白水 元, 佐々真志, 宮武 誠：砂浜底質の波の遡上に 伴う間隙変化モニタリング手法の開発, 土木学会論文 集 B3(海洋開発 ), Vol.73, No. 2, I_702-I_706, 2017.
5) 宮武 誠, 阿部翔太, 木村克俊, 越智聖志: 底質粒 径による飽和・不飽和浸透流が波打ち帯の漂砂移動 に及ぼす影響, 土木学会論文集 B2( 海岸工学), Vol. 69, No.2, I_076-I_080, 2013.

6) 柴山知也, Nguyen The Duy: 砕波帯内乱流モデルの波打 ち帯 (Swash Zone) への拡張, 海岸工学論文集, 第 49 巻, pp.451-455, 2002.

7) R. Bakhtyar, D.A. Barry, A. Yeganeh-Bakhtiary, A. Ghaheri:Numerical simulation of surf-swash zone motions and turbulent flow, Advances in Water Resources 32, pp.250-263, 2009.

8) Bear, J. : Hydraulics of Groundwater, McGraw-Hill, pp.190224, 1979.

9) Irmay, S.: On the hydraulic conductivity of unsaturated soils, Trans. AGU., Vol.35, pp.463-467, 1954.

10) Van-Genuchten, M. T. : A closed-form equation for predicting the hydraulic conductivity of unsaturated soils, Soil Science Society of America Journal, Vol.44, pp. 892-898, 1980.

11) Rubey, W. W. : Settling velocities of gravel, sand, and silt, American J. of Science, vol 25, No.148, 1933.

12) Nielsen, P. : Coastal bottom boundary layers and sediment transport, World Scientific, pp.224-226, 1992.

13) 中村友昭, 水谷法美 : 浮遊砂の移流拡散現象を解析で きる三次元数值計算モデルの構築とその適用に関する 一考察, 土木学会中部支部研究発表会, II-008, pp.131132, 2010.

14) Masselink, G., P. Russel, I. Turner, C. Blenkinsopp: Net sediment transport and morphological change in the swash zone of a highenergy sandy beach from swash event to tidal cycle time scales, Marine Geology 267, pp.18-35, 2009.

15) Tuner, I. L. , Masselink, G. : Swash infiltration-exfiltration and sediment transport, J. Geophys. Res., Vol. 103, pp.3081330824, 1998.

16) Butt, T., P. Russel and I. Turner: The influence of swash infiltration-exfiltration on beach face sendiment transport: onshore or offshore?, Coastal Eng., Vol.42, pp.35-42, 2001.

(2018.3.15 受付)

\title{
PREDICTION OF SEDIMENT TRANSPORT IN SWASH ZONE CONSIDERING SATURATED-UNSATURATED GROUNDWATER FLOW
}

\author{
Makoto MIYATAKE, Sakura ISHIBASHI, Katsutoshi KIMURA, Masashi OCHI, \\ Shinji SASSA and Hajime SHIROZU
}

Numerical simulations are performed to evaluate sediment transport affected by saturation of a beach slope in the swash zone. The wave transformation and groundwater flow are estimated using the Reynolds model describing the average motion of turbulent flow coupled with the saturated-unsaturated seepage flow model. The advection diffusion model is used to compute the transport of suspended sediment in the swash zone. Nielsen formula, which estimates the pickup rate of sediment, is applied as the bottom boundary condition. The infiltration-exfiltration effects are quantified through a permeable Shields parameter. The comparison between present model results and previous experimental data show that, in the case of fine sand, the characteristics of sediment transport due to saturation of a beach slope can be evaluated by changes in the effective weight of sediment due to infiltration-exfiltration flow. 